\title{
Recurrent urinary tract infections in a patient with Crohn's disease
}

\author{
Jurgen Gerada, Mario Vassallo
}

Department of Gastroenterology, Mater Dei Hospital, Msida, Malta

Correspondence to Dr Jurgen Gerada, jurgen.gerada@gmail.com

\section{DESCRIPTION}

A 62-year-old male smoker was diagnosed with ileocolonic Crohn's disease 1 year previously, which was complicated by an asymptomatic terminal ileal stricture diagnosed on contrast radiology. Clinical and biochemical remission were induced initially by steroids and then maintained by mesalazine ( $1 \mathrm{~g}$ three times a day) and azathioprine $(2 \mathrm{mg} / \mathrm{kg}$ daily). Six months following diagnosis, the patient complained of recurrent urinary tract infections and haematuria, and was found to have raised inflammatory markers, hypoalbuminaemia and anaemia. CT scan of the abdomen showed an internal fistula (figure 1, arrow) with calcification, between a thickened terminal ileum and the right posterior bladder wall. A small gas bubble was seen in the bladder (figure 2, arrow). Surgical excision of the terminal ileum, closure of the fistula and enterocolic anastomosis was thus carried out. Histology of the resected specimen showed active Crohn's disease. Following surgery, he resumed azathioprine $(2.5 \mathrm{mg} / \mathrm{kg}$ daily) and soon after was started on infliximab therapy. He has since remained in remission.

Enterovesical fistula is a well-known recognised complication of terminal ileal Crohn's disease and may occur at any age and at any stage of the disease. ${ }^{1}$ Fistulating terminal ileal Crohn's disease preferentially involves the bladder, given the close anatomical relationship between these two structures. A high level of suspicion should be

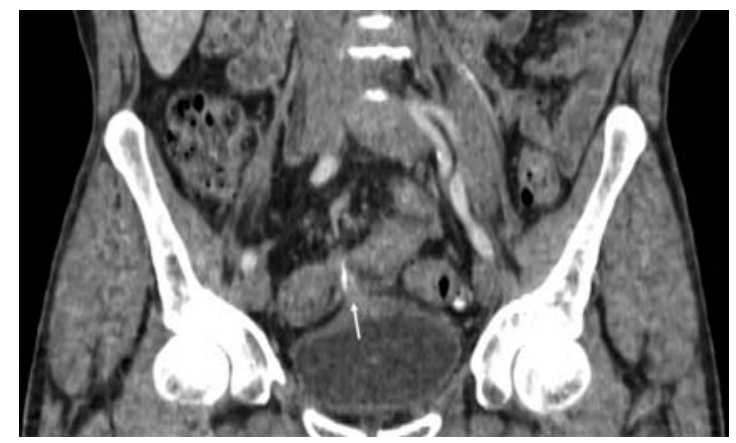

Figure 1 Internal fistula connecting the terminal ileum with the right posterior bladder wall.

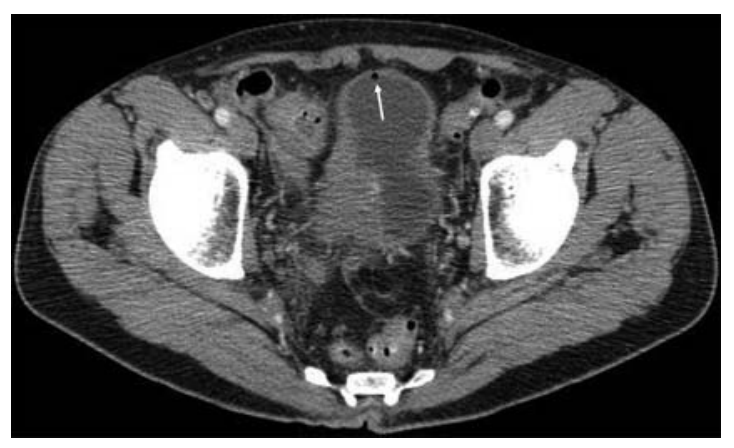

Figure 2 Small gas bubble within the bladder.

maintained and due attention given, when symptoms such as pneumaturia (often the first clinical symptom), recurrent urinary tract infections or fecaluria are reported by Crohn's patients. CT of the abdomen is a sensitive and non-invasive method of detecting this complication. ${ }^{2}$

\section{Learning points}

- Fistulating terminal ileal Crohn's disease preferentially fistulates to the bladder due to close proximity of the two structures.

- Pneumaturia or persistent urinary symptoms in patients with Crohn's disease should alert the physician to screen for an enterovesical fistula.

- From current medical knowledge, surgery is the preferred approach for enterovesical fistulae.

Competing interests None.

Patient consent Obtained.

\section{REFERENCES}

1. Kollias G, Rinsche KG. Ileovesical fistula in Crohn's disease (author's transl). MMW Munch Med Wochenschr 1979;121:1489-90.

2. Merine D, Fishman EK, Kuhlman JE, et al. Bladder involvement in Crohn disease: role of $\mathrm{CT}$ in detection and evaluation. $\mathrm{J}$ Comput Assist Tomogr 1989;13:90-3. 


\section{BMJ Case Reports}

Copyright 2012 BMJ Publishing Group. All rights reserved. For permission to reuse any of this content visit http://group.bmj.com/group/rights-licensing/permissions.

BMJ Case Report Fellows may re-use this article for personal use and teaching without any further permission.

Please cite this article as follows (you will need to access the article online to obtain the date of publication).

Gerada J, Vassallo M. Recurrent urinary tract infections in a patient with Crohn's disease. BMJ Case Reports 2012;10.1136/bcr-2012-007356, Published XXX

Become a Fellow of BMJ Case Reports today and you can:

- Submit as many cases as you like

- Enjoy fast sympathetic peer review and rapid publication of accepted articles

- Access all the published articles

- Re-use any of the published material for personal use and teaching without further permission

For information on Institutional Fellowships contact consortiasales@bmjgroup.com

Visit casereports.bmj.com for more articles like this and to become a Fellow 